\title{
Impressions from the 2013 EURUFU Summer School Lungau
}

\author{
Heidi Humer-Gruber
}

Keywords: summer school, Salzburger Lungau Biosphere Reserve, regional development, interdisciplinarity

\section{Abstract}

Who says only cities offer the infrastructure to provide professional training? The Salzburger Lungau Biosphere Reserve took the challenge and brought the university to the country by hosting 37 students for three weeks.

A team of experts from four universities and various disciplines related to regional development and architecture supervised the motivated crowd. External speakers gave the students an understanding of their field of expertise in a very practical way, while the afternoons were dedicated to group work on the various projects.

After explaining the background and how the summer university came to be established, this article gives an idea of what the students worked on and the experiences they gained during these intense three weeks. One project is explained in more detail to provide an example. Personal impressions complement the report, together with a look at the unintended effects of the teaching efforts.
Profile

Protected area

Salzburger Lungau Biosphere Reserve

Mountain range

Alps

Country

\section{Austria}

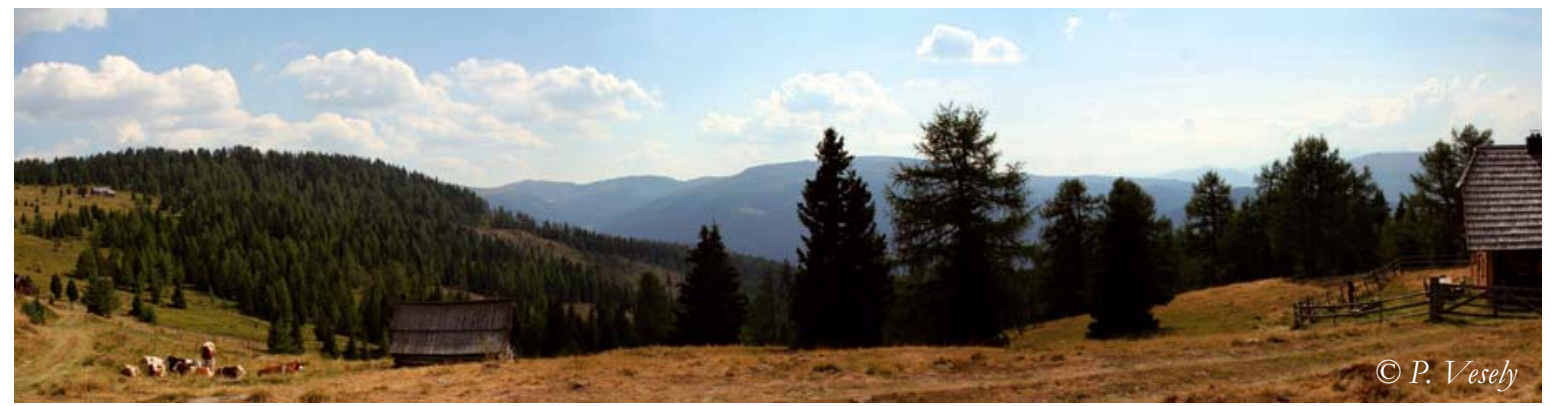

\section{Introduction}

How the Summer School evolved

The Salzburger Lungau Biosphere Reserve is a very young biosphere reserve (BR), established in 2012. For the period 2011 to 2014, the Lungau has been chosen as a model region for the transnational EU project EURUFU (European Rural Futures). One of the sponsored projects is the EURUFU Summer University 2013, which was held in Tamsweg from 5-23 August 2013.

It was attended by 37 students from the University of Natural Resources and Life Sciences (BOKU Wien), the University of Innsbruck, the Vienna University of Technology (TU Wien), the University of Salzburg and the University of Art and Design Linz (Kunstuniversität Linz), drawn from the disciplines of architecture, landscape planning, landscape architecture, regional planning, political science, geography and other related disciplines. They spent three weeks in Tamsweg to listen to a variety of lectures and to work in small interdisciplinary groups on predetermined projects.

The solution-oriented concepts and outcomes of the projects, based on sustainable development as defined by the BR, were shown to the local public, stakeholders and decision makers in a final presentation.
Background of the Summer School - bringing Heidi back

The Summer School was designed under the title EURUFU is bringing Heidi back, referring to a study which took place in Lungau in 2001, which was entitled Heidi wohnt hier nicht mehr - on the emigration of the autochthonous creative and innovative potential from the rural regions. (Fuchshofer et al. 2001). Heidi doesn't live here anymore is a synonym for the lack of opportunity to use this innovative and creative potential, the knowledge and skills in the area of origin, to establish a livelihood and to contribute to the development or at least to the preservation of the region (Fuchshofer et al. 2001).

Brain drain is a major problem in many rural areas

An indirect goal of the summer school was demonstrating to the students that there is a need for their knowledge, creativity and expertise, and that there probably are jobs for them at their places of origin.

The students were warmly welcomed by various mayors in Lungau, who explained the objects to be resurrected in the concepts developed during the summer school. In nearly every community beautiful central buildings, some of them under preservation orders, are close to collapse as they haven't been used 
for decades. Village centres with their old buildings are at risk of dying while at the edge sprawling developments are setting in.

Though these buildings are formative for the appearance of the villages, they may have been empty for decades. Everything points to a demographic change and young people are needed in the rural areas as they are the future generations who keep the area alive. The strengths of rural areas are the scenery with its calmness and the high quality of living, which is not comparable to urban areas characterized by pressure and noise, especially for young families with children.

However, there are many constraints for young academics trying to move back to their places of origin. One major constraint is probably the absence of job opportunities in their field of expertise. A vicious circle sets in when young people move to more attractive urban areas: then there are not enough children to finance proper education and daycare facilities for children, which are important criteria for young families when deciding to settle in the area.

\section{Assignments for the students}

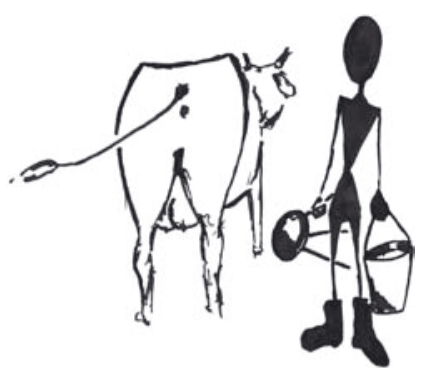

(C) S. Matscher
The overall requirements were using regional resources in terms of construction material as well as regional products and handicrafts. The spirit of the BR should be invoked by including the needs of local stakeholders in the planning processes and strengthening the regional economy. The assignments were planned in cooperation with the mayors and community representatives.

Students could work on eleven very practical projects covering a wide spectrum of themes: a BR centre is needed for the offices of the BR management, for raising awareness among the local community and as portal for the visitors to the BR.

Mobility is a problematic issue in Lungau as the main means of transport is the private car. A sustainable, efficient public transport system is needed, therefore one group tried to find solutions for improving the current mobility situation. Another group worked on the concept how empty mountain huts might be used, while a third group tried to find a way to educate people on the uniqueness and special features of the Natura 2000 area Seetaler See, which includes Austria's biggest quaking bog. Additional topics included the renaturation of the Thomatalerbach by implementing a local recreation area and an Ornithological Research Centre planned in Lungau. New life in old walls was the theme for five groups in different communities who were looking for new ways of utilizing old, beautiful but empty buildings with great significance for the relevant community.
Aims and outcomes of the Summer School and its relation to the $B R$

Some of the presented projects were realizable, at least in part, while others covered very visionary concepts way beyond the community budget. The students dealt with the topics during very intense three weeks and offered their ideas to the local communities and their mayors. These ideas can be seen as a starting point for discussions, further visions and for raising awareness in the community that it is their turn to change and construct places and meeting spaces.

The students had not been to Lungau before and valued the calm area, its scenic beauty, intact refugium and undisturbed privacy, which are often no longer noticed by the local people. They tried to involve as many local opinions as possible in their projects within their short period of information gathering.

Students entered the BR with the view of outsiders and were able to obtain answers on sensitive questions that insiders would never have dared to ask. This innocent approach was probably new to the inhabitants, but it might encourage them to get involved and trigger a more do-it-yourself mentality in regional development.

Over decades inhabitants were meant to leave all tasks to the local authority, but a new paradigm needs to be evolved. Power structures are changing, which is welcomed by the local authorities. Communities don't have the money to care for everything and rely more and more on active, dedicated inhabitants. This helps to strengthen the local communities and their social capital.

\section{Project Seetaler See}

In 1995 the landscape conservation area Seetaler See in Tamsweg was designated a Natura 2000 area following the FFH directive. As one of the most demanding conservation sites in Austria, Seetaler See is part of the core zone in Salzburger Lungau BR. The moor lake and its $500 \mathrm{~m}$ shore area hosts a unique flora and fauna. It is especially valuable as Austria's biggest quaking bog and includes significant ecosystems in good conditions, like creeping pine peat bogs and extensively mowed calcareous grasslands. In the European and international context, the lake and its moor are an extraordinary place for discovering rare plants and microflora, though in the regional context only few people know about its existence and importance. In order to protect the area for the future the students' task was to design a concept for using this invaluable area:

A SWOT analysis made clear that the requirements of the Natura 2000 area are inalienable and rising awareness is a major issue in their project. They came up with an interactive nature trail for children between six and twelve years. Blackboards communicate an appreciation of these unique ecosystems. In a playful manner with interactive nature games children are given an understanding of the characteristics of the 


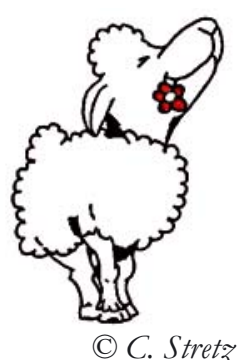

area. The trail might be used for guided tours, individual visitors or by local schools as a green classroom. The information boards tell an exciting story about Ricki the sheep who is bored of its life in the countryside and goes on an adventure trip. Along the way it passes various stations where it meets desmids and the Northern

Emerald, who tell Ricki about the treasure of the Seetaler See. It's the nature's treasure children should become aware of in a cheerful way.

The architectural approach provides a barrier-free trail with bridges, overhead crossings and viewing platforms which invite the visitors to linger in the natural scenery without harming the sensitive ecosystem. With this interactive nature trail the beauty and the value of the area might be actively experienced and it offers an opportunity for knowledge transfer within the BR while ensuring the protection of the sensitive ecosystem.

Personal impressions and what the students took home

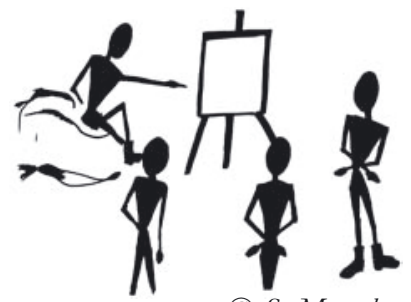

Three weeks are nowhere near enough time to become a regional expert and come up with final cost calculations of restoration plans for vacant historic buildings, this would be quite unrealistic. Nevertheless, some students tried to do just that, worked through nights and ended up with signs of exhaustion. The Summer University was an outstanding opportunity for students to work on reallife items and issues, in great contrast to the theoretical approaches common at the universities. Their enthusiasm was fed by the possibility of their projects actually being realized.

Even so, three weeks are enough to get an idea of the problems faced in the region. The students coming from other places than Lungau had a very openminded approach to the problems and tasks offered by the summer school, which was seen as a huge advantage. Many students made their way to Tamsweg via public transport and experienced first-hand the deficits of the present mobility system. They had a healthy disregard for political allegencies and developed quite unbiased concepts. They offered ideas and it's up to the local communities to pick out the parts they want to work on.

Yet students are not immune to being influenced and I would critically question the interests of some advisors. Nevertheless, the students operated critically enough. For them it was a golden opportunity to experi-

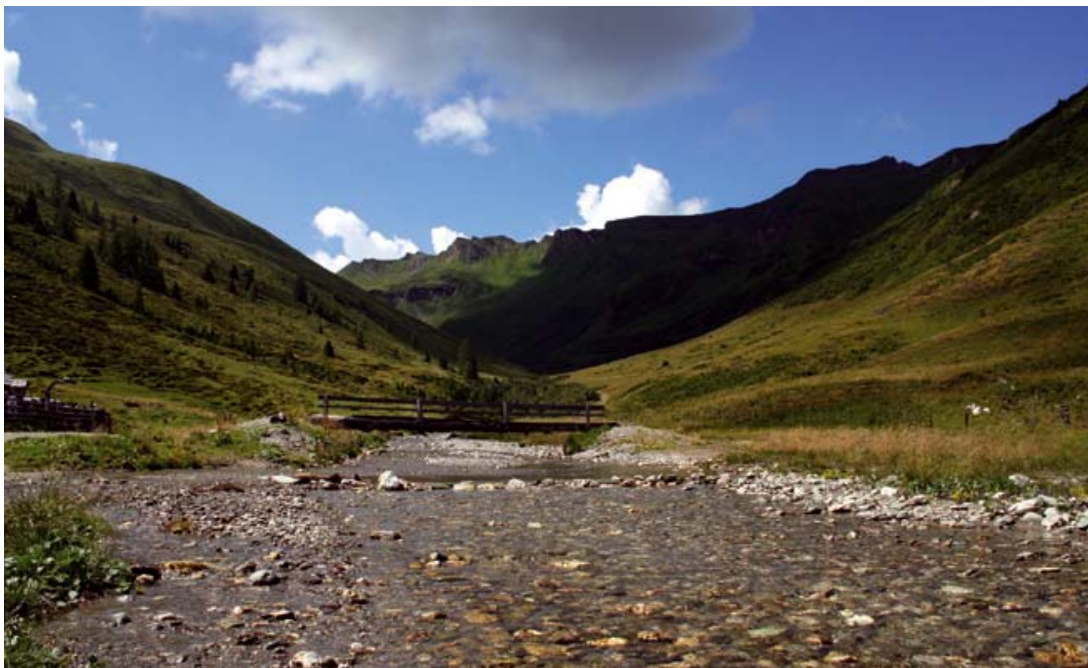

Alpine pasture hike Riedingtal. (C) P. Vesely

ence the structures of regional politics in conversation with very frank mayors on the one hand, while discovering the hidden agenda of some scientists on the other. These were lessons with great significance for our future lives as professionals, which cannot be taught within the safe theoretical context of the universities.

Another very important lesson was working in interdisciplinary small groups. This created problems nobody had thought about beforehand, for example ,appreciating the work spent on architectural construction programmes. Someone who has never worked on it cannot imagine how many hours you may spend on it. Nevertheless, every student tried to give his/her best and bring in their field of expertise. It was amazing to experience the process of understanding within the small groups, which were very heterogeneous in terms of disciplines.

Unfortunately working interdisciplinarily seems to be easier for students than for researchers and scientists. Some behaved like top dogs and left no space for any other opinion or approach, while the students managed to give their most feasible input to be used for a positive outcome of their projects. Some advisors, who spent the whole three weeks with the students, had the challenging task of keeping them motivated and combating various frustration levels. The students greatly appreciated this kind of support and assistance.

What interdisciplinary work needs is a group of people who are open to new ideas and who allow other opinions than those of their known field. It needs humanity, respect on a personal level and openness for other disciplines. It's necessary to appreciate a person's knowledge and work in this other discipline. The students had to find out in the small groups what their strengths were and how they might plan their project in a way that employed all their skills as a team. And all this to be achieved within three weeks!!! The excellent sessions in the mornings, conducted by external lecturers, gave students an insight into other fields and various practical and unconventional ways of implementation in their own disciplines. 


\section{Overall impression and outlook}

The students were welcomed by the mayors with great expectations and overwhelming excitement about having the graduates in town. With this enthusiasm and motivation, I hope the Summer School in Lungau will be held again in years to come. Students gained a practical insight into regional politics and regional development. They learned lessons which are not taught at universities but essential in working lives. They also took home great impressions from the BR and will spread the word about the beauty of the area and the welcoming people they met there. What happens with their projects remains to be seen, but some might be realized and this would be a great honour for the students.

\section{References}

Fuchshofer, R., K. Eckstein \& M. Wullner 2001. Heidi wohnt hier nicht mehr. Zur Abwanderung des autoch- thonen kreativen und innovativen Potentials aus dem ländlichen Raum. Eine sozialwissenschaftliche Analyse zur Situation im EU Ziel 2 Gebiet Lungau und Lösungsansätze zur Aktivierung des internen Innovationspotentials. Projekt des Jubiläumsfonds der Österreichischen Nationalbank Nr. 8347. Projektbericht. Available at: http://www.stadtlandberg.at/heidi/index.htm (accessed 27/08/2013)

\section{Author}

Heidi Humer-Gruber studied Ecology and Biodiversity in Graz and Natural Resource Management in Vienna (BOKU) and New Zealand until 2009. Two years as dairymaid and herdswoman on a Swiss Alp awoke her interest in sustainable agriculture and nature conservation in the Alpine regions.

Institute for Interdisciplinary Mountain Research, Austrian Academy of Sciences, Technikerstr. 21a, 6020 Innsbruck. Contact: heidihg@gmx.at 